Marian Kallas

Wyższa Szkoła Finansów i Zarządzania w Warszawie e-mail: goruch@vizja.pl telefon: +48225365435

DOI: $10.15290 /$ mhi.2015.14.01.13

\title{
Pozycja ustrojowa marszałka Sejmu w projektach konstytucyjnych z lat 1989-1991
}

\begin{abstract}
SUMMARY
The Position of the Speaker of the Sejm in the Drafts of the Polish Constitution 1989-1991
\end{abstract}

The text evaluates the proposed regulations of the position of the ruling and auxiliary organs in Polish parliament (Sejm). The analyzis covers 11 drafts of the Polish constitution from 1989-1991. Among them there were: 2 parliamentary drafts, 4 coming from parties and 5 private ones.

The vast majority of drafts concentrated on the position of the Speaker of the Sejm (so called Marshal). Only in two drafts, mainly in the draft prepared by the Senat in 1991, was the position of the Marshal weakened in favour of the Prezydium Sejmu, a collegial body which was supposed to steer the activity of both chambers of the Polish parliament. The further internal law of both chambers was supposed to determine the role and the structure of the internal organs of the parliament.

Key words: Polish Constitution, Sejm, Senat, Speaker, Marshal of the Sejm

Słowa kluczowe: marszałek Sejmu, Konstytucja, parlamentaryzm polski, Senat

Przedmiotem opracowania jest charakterystyka postulowanych regulacji prawnych określających pozycję ustrojową organów wewnętrznych parlamentu. W ich obrębie znajdują się organy kierownicze i organy pomocnicze obu izb. W pierwszym rzędzie chodzi o określenie pozycji marszałka Sejmu wynikającej z proponowanych rozwiązań zawartych w projektach polskich ustaw zasadniczych z lat 1989-1991.

Zasadniczą cezurę we współczesnych dziejach państwa w Polsce stanowi rok 1989. Wówczas rozpoczął się ewolucyjny proces transformacji ustrojowej, która doprowadziła do ukształtowania się Trzeciej Rzeczypospolitej (od 1989 r.). Uznaję trafność stwierdzenia, iż w latach 1989-1992 rozpoczął 
się pierwszy okres transformacji ustrojowej, której rezultatem było uchwalenie demokratycznej ustawy zasadniczej z 2 kwietnia 1997 r. (druga Konstytucja kwietniowa).

W toku obrad Okrągłego Stołu trwających od 6 lutego do 5 kwietnia 1989 r. doszło do zawarcia doniosłego kontraktu politycznego w postaci Porozumień Okragłego Stołu. Najważniejszym z nich było Stanowisko w sprawie reform politycznych z 5 kwietnia 1989 r. ${ }^{1}$, określające zasady mające doprowadzić do przyjęcia demokracji parlamentarnej w Polsce. Zadaniem nowego dwuizbowego parlamentu miało być uchwalenie nowej, demokratycznej Konstytucji oraz demokratycznej ordynacji wyborczej. Czasowo zgodzono się na utrzymanie zasady, że "Sejm pozostaje najwyższym organem władzy ustawodawczej". W istocie była to pewna nieścisłość, ponieważ według Konstytucji Polskiej Rzeczypospolitej Ludowej z 22 lipca 1952 r. Sejm był najwyższym organem władzy państwowej (art. 20). Omówiony dokument z 5 kwietnia 1989 r. zawierał ważne sformułowanie: "Senat będzie wraz z Sejmem uczestniczył w nowelizowaniu i uchwalaniu Konstytucji". Porozumienia Okragłego Stołu to akt polityczny, na podstawie którego nastąpiły zmiany konstytucyjne $\mathrm{w}$ postaci kolejnych nowelizacji ustawy zasadniczej z $1952 \mathrm{r}$. Oznaczało to usankcjonowanie programu reform ustrojowych przyjętych w czasie obrad Okrągłego Stołu.

Pierwszą zmianę Konstytucji lipcowej z 1952 r. była nowela z 7 kwietnia 1989 r. ${ }^{2} \mathrm{Na}$ tej podstawie zmieniono konstytucyjny system organów państwowych. Nowela kwietniowa z 1989 r. przywróciła Senat, co oznaczało powrót do dwuizbowego parlamentu. Sejm uzyskał przewagę nad Senatem, będącym izbą drugą.

Po sukcesie wyborczym „Solidarności” z 4 czerwca 1989 r. powszechnie spodziewano się rychłego uchwalenia nowej polskiej konstytucji. W następstwie uznania nierealności tego zamierzenia zdecydowano się na przeprowadzenie niezbędnych zmian $\mathrm{w}$ Konstytucji PRL. Jak się okazało, rozpoczęte w 1989 r. prowizorium konstytucyjne utrzymało się aż do $1997 \mathrm{r}$.

Wbrew oczekiwaniom dopiero w grudniu 1989 r. rozpoczęły się prace projektodawcze nad przyszłą konstytucją. W związku z tym 7 grudnia 1989 r. powołano najpierw sejmową, a następnie senacką Komisję Konstytucyjną. Opracowywanie dwóch osobnych projektów ustawy zasadniczej wywołało krytyczne uwagi. Głównie ze strony sił pozaparlamentarnych odmawiano prawnego i moralnego tytułu do uchwalenie ustawy zasadniczej przez parlament wybrany w 1989 r. Jednakże obie Komisje opracowały w 1991 r. projekty konstytucji. Rozwiązanie niebawem Sejmu X kadencji i Senatu I kadencji oznaczało

1 Porozumienia Okragłego Stołu. Warszawa 6 luty - 5 kwietnia 1989 r. Olsztyn 1989, s. 5-12.

2 Dziennik Ustaw Polskiej Rzeczypospolitej Ludowej (dalej: Dz.U. PRL) z 1989 r., Nr 19, poz. 201. 
niespełnienie misji parlamentu, polegającej na uchwaleniu nowej ustawy zasadniczej. Wyłoniony w demokratycznych wyborach z 27 października $1991 \mathrm{r}$. parlament, funkcjonujący w charakterze konstytuanty, kontynuował prace nad nową ustawą zasadniczą. 30 października 1992 r. do pracy przystąpiła Komisja Konstytucyjna. Należy zarazem wskazać na doniosłe znaczenie następnej zmiany Konstytucji lipcowej z 27 grudnia 1989 r. Nowela grudniowa oznaczała w istocie rewizję aktu z 22 lipca 1952 r. Zawierała nowe zasady funkcjonowania państwa, w tym konstytucyjną definicję „Rzeczypospolita Polska jest demokratycznym państwem prawnym, urzeczywistniającym zasady sprawiedliwości społecznej" (art. 1). Niezależnie od prac nad parlamentarnymi projektami nowej ustawy zasadniczej w latach 1989-1991 zredagowano szereg innych projektów konstytucyjnych charakteryzujących się znaczną różnorodnością propozycji regulacji prawnych. Projekty te w znacznej części wyrażają koncepcje rozwiązań ustrojowych wyrażonych podczas obrad „okrągłego stołu".

Najważniejsze $\mathrm{z}$ tych tekstów, łącznie $\mathrm{z}$ dwoma projektami komisji parlamentarnych, złożyły się na zbiór liczący jedenaście pozycji, zatytułowany Projekty konstytucyjne 1989-1991 r., który został opublikowany przez Wydawnictwo Sejmowe ${ }^{3}$. Problematyka ta wzbudzała rosnące zainteresowanie, czego wyrazem jest zwłaszcza praca Ryszarda Chruściaka i Wiktora Osiatyńskiego Tworzenie Konstytucji w Polsce w latach 1989-19974.

W Projektach konstytucyjnych zamieszczono następujące teksty projektów:

1. Konstytucja Rzeczypospolitej Polski, projekt przygotowany przez Komisje Konstytucyjną Sejmu Rzeczypospolitej Polskiej (tekst z 24 sierpnia 1991 r. ${ }^{5}$ ),

2. Konstytucja Rzeczypospolitej Polskiej, projekt uchwalony przez Komisje Konstytucyjną Senatu Rzeczypospolitej (wersja z 22 października 1991 r. ${ }^{6}$ ),

3. Tezy do Konstytucji Rzeczypospolitej Polskiej, projekt Stronnictwa Demokratycznego (tekst z 9 stycznia $1990 \mathrm{r.}^{7}$ ),

4. Konstytucja Rzeczypospolitej Polskiej, projekt Polskiego Stronnictwa Ludowego $\left(1990 \mathrm{r}^{8}\right)$,

5. Założenia Projektu Konstytucji Rzeczypospolitej, projekt Porozumienia Centrum (1991 r. $\left.{ }^{9}\right)$,

3 Projekty konstytucyjne 1989-1991, do druku przygotował M. Kallas (dalej: Projekty konstytucyjne), Warszawa 1992, s. 386.

4 R. Chruściak, W. Osiatyński, Tworzenie Konstytucji w Polsce w latach 1989-1997, Warszawa 2001, s. $13-76$.

5 Projekty konstytucyjne, s. $19-53$.

6 Ibidem, s. 54-94.

7 Ibidem, s. 95-116.

8 Ibidem, s. 117-140.

9 Ibidem, s. 141-145. 
6. Konstytucja Rzeczypospolitej Polskiej, projekt Konfederacji Polski Niepodległej $\left(1991\right.$ r. $\left.^{10}\right)$,

7. Projekt tez normatywnych nowej Konstytucji, opracował Mieczysław Huchla $\left(1989\right.$ r. $\left.{ }^{11}\right)$,

8. Projekt Konstytucji Rzeczypospolitej Polskiej, projekt Józefa Lityńskiego $\left(1990\right.$ r. $\left.^{12}\right)$

9. Konstytucja Rzeczypospolitej Polskiej, projekt opracował zespół pod kierownictwem Sylwestra Zawadzkiego (1990 r. ${ }^{13}$ ),

10. Konstytucja Rzeczypospolitej Polskiej, projekt opracowali Janina Zakrzewska i Jerzy Ciemniewski (1990 r. $\left.{ }^{14}\right)$,

11. Projekt Konstytucji Rzeczypospolitej Polskiej, projekt opracowali Andrzej Mycielski i Wacław Szyszkowski (1991 r. $\left.{ }^{15}\right)$.

Poza projektami sejmowej i senackiej Komisji Konstytucyjnej zbiór obejmuje cztery projekty partii politycznych oraz pięć projektów prywatnych.

Niżej charakteryzuję postulowane usytuowanie organów wewnętrznych parlamentu w poszczególnych projektach ustawy zasadniczej.

Konstytucja Rzeczypospolitej Polskiej. Projekt z 24 sierpnia 1991 r. przygotowany przez Komisję Konstytucyjną Sejmu Rzeczypospolitej Polskiej. Rozdział 3 tego projektu zatytułowano Sejm i Senat (art. 49-88). Zgodnie z projektem "Sejm jest organem przedstawicielskim narodu" (art. 49). Sejm jest izbą pierwszą składającą się z 444 posłów wybieranych na czteroletnią kadencję (art. 49). Projekt ustalał strukturę organów wewnętrznych Sejmu (art. 58) i uznaje za organy kierownicze tej izby marszałka Sejmu i Prezydium Sejmu. W skład tego organu kolegialnego wchodzą marszałek i wicemarszałkowie. Projekt przyjmuje tradycyjną formułę, według której „Prezydium kieruje pracami Sejmu". Spośród posłów dokonuje się wyboru marszałka i wicemarszałków oraz komisji (będących organami pomocniczymi). Sejmowy projekt konstytucji z $1991 \mathrm{r}$. kompetencję zwoływania posiedzeń Sejmu powierza Prezydium Sejmu (art. 58, ust. 1), z wyjątkiem pierwszego posiedzenia izby, którego dokonuje Prezydent. Projekt konstytucji przyjmuje, że „Szczegółową organizację i tryb pracy Sejmu określa regulamin uchwalony przez Sejm w formie uchwały" (art. 63). Omawiany projekt zawiera dwuwariantową koncepcję izby drugiej (art. 80). "Senat jest reprezentacją samorządu terytorialnego, powołaną do współudziału w stanowieniu ustaw", składającą się ze 111 senatorów (wariant drugi). Według pierwszego wariantu „Senat składa się ze 100 senato-

\footnotetext{
10 Ibidem, s. 146-186.

11 Ibidem, s. 187-205.

12 Ibidem, s. 206-246.

13 Ibidem, s. 247-288.

14 Ibidem, s. 289-316.

15 Ibidem, s. 317-337.
} 
rów wybieranych w województwach na okres kadencji Sejmu". Struktura organów wewnętrznych Senatu była identyczna z organizacją sejmową (art. 86). Istotne znaczenie ma uznanie $\mathrm{w}$ projekcie konstytucji z 24 sierpnia $1991 \mathrm{r}$. za organy kierownicze parlamentu Prezydium Sejmu i odpowiednio Prezydium Senatu.

Konstytucja Rzeczypospolitej Polskiej. Projekt Komisji Konstytucyjnej Senatu Rzeczypospolitej Polskiej w wersji z 22 października 1991 r. Najważniejsze regulacje dotyczące parlamentu zawiera rozdz. IV zatytułowany Władza ustawodawcza (art. 60-84). W senackim projekcie przyjęto tradycyjne - z czasów Pierwszej Rzeczypospolitej - nazwy izb, a mianowicie: Izba Poselska i Senat łącznie stanowiących Sejm (art. 60). Posłów w liczbie 444 wybierano na czteroletnią, a 100 senatorów na sześcioletnią kadencję. Regulacje dotyczące struktury organów wewnętrznych Sejmu łącznie obejmują obie izby (art. 74). Wybory marszałka, wicemarszałków, komisji (organy pomocnicze) dokonywano osobno w Izbie Poselskiej (izba pierwsza) i Senacie (izba druga). Według projektu senackiego "Marszałek kieruje obradami i czuwa nad tokiem prac Izby" (art. 74, ust. 2). Postulowano więc powołanie marszałka jako jednoosobowego organu kierowniczego w każdej z Izb. Natomiast pierwsze posiedzenie nowo wybranej Izby Polskiej zwołuje Prezydent. Prezydium Sejmu oraz Konwent Seniorów nie uzyskały statusu organów konstytucyjnych. Obok komisji stałych, projekt przewidywał powołanie komisji „do zbadania określonej sprawy”. Także omawiany projekt konstytucji uznawał, że „Każda z Izb Sejmu uchwala własny regulamin i zatwierdza swój budżet". Charakterystycznym dla senackiego projektu konstytucji z 1991 r. było zapewnienie szerokich kompetencji marszałkowi jako jednoosobowemu organowi kierowniczemu każdej z Izb Sejmu.

Tezy do Konstytucji Rzeczypospolitej Polskiej. Tekst projektu Stronnictwa Demokratycznego z 9 stycznia 1990 r. Uregulowania na temat parlamentu znajdują się w części zatytułowanej Sejm i Senat (tezy 55-68). W tej dziedzinie przyjęto rozwiązanie wariantowe polegające na wprowadzeniu jednoizbowego parlamentu. Sejm (izba pierwsza) miał liczyć 460 posłów wybieranych na czteroletnią kadencję, a do Senatu (izba druga) wybierano 115 senatorów, także na czteroletnią kadencję. Projekt Konstytucji Stronnictwa Demokratycznego (SD) zawierał łączną regulację dotyczącą organów kierowniczych i pomocniczych obu izb, to jest Sejmu i Senatu (teza 61). Organami kierowniczymi byli marszałek i wicemarszałek Sejmu oraz marszałek i wicemarszałek Senatu. Projekt SD powierzał marszałkowi i wicemarszałkom Sejmu i Senatu kierowanie pracami każdej z izb oraz czuwanie nad tokiem ich prac. Projekt konstytucji przyznawał jeszcze status organu konstytucyjnej Prezydium Sejmu i Senatu. Tryb ich powołania miał określić regulamin każdej z izb. Omawiany projekt konstytucji rozróżniał komisje zwyczajne (stałe) i komisje nadzwyczajne, które były organami pomocniczymi Sejmu i Senatu. Ich tryb powołania miał określić re- 
gulamin każdej z izb. Cechą charakterystyczną projektu Konstytucji SD było uznanie marszałków i wicemarszałków Sejmu i Senatu za jednoosobowe organy kierownicze w każdej z izb.

Konstytucja Rzeczypospolitej Polskiej. Projekt ustawy zasadniczej Polskiego Stronnictwa Ludowego z 1990 r. Bardzo zróżnicowaną problematykę zawiera rodz. III noszący tytuł Publiczne organy władzy, administracji i samorządu terytorialnego. W jego obrębie wyróżniono część A dotyczącą Sejmu (art. 42-49) oraz część B odnoszącą się do Izby Samorządowej (art. 50-51). Projekt Konstytucji Polskiego Stronnictwa Ludowego (PSL) przyjął zmodyfikowaną strukturę bikameralizmu obejmującą Sejm (izba pierwsza) i Izbę Samorządową, określoną jako druga Izba Parlamentu (art. 50). Projekt konstytucji przewidywał zwołanie pierwszego posiedzenia nowo wybranego Sejmu przez Prezydenta. Według projektu Konstytucji PSL „Sejm jest najwyższym organem władzy w państwie" (art. 42). Stanowi to w istocie nieznaczną modyfikację art. 20 Konstytucji Polskiej Rzeczypospolitej Ludowej z 22 lipca 1952 r. w brzmieniu ustawy z 10 lutego 1976 r.: „Najwyższym organem władzy państwowej jest Sejm Polskiej Rzeczypospolitej Ludowej"16. Sejm składał się 460 posłów wybieranych na czteroletnią kadencję, a Izba Samorządowa miała liczyć 100 posłów. Projekt konstytucji przyjmował, że Sejm wybiera marszałka, wicemarszałków i komisje. Omawiany projekt przyjął konstrukcję, zgodnie z którą „Marszałek lub w jego zastępstwie wicemarszałek kieruje obradami i czuwa nad tokiem prac Sejmu". Według projektu organami pomocniczymi Sejmu były komisje stałe oraz komisja doraźna (nadzwyczajna). Charakterystycznym dla projektu Konstytucji PSL było uznanie marszałka i wicemarszałków za jednoosobowe organy kierownicze Sejmu.

Założenia projektu Konstytucji Rzeczypospolitej Polskiej. Tekst Porozumienia Centrum z 1991 r. Jest to zbiór postulatów, niewyczerpujących nawet minimum materii konstytucyjnej. Według założeń projektu władza ustawodawcza należy do osobno działających Sejmu i Senatu. Sejm składa się z 444 posłów wybranych na czteroletnią kadencję, a Senat z 111 senatorów wybieranych na sześcioletnią kadencję. Założenia przyjęły sesyjny tryb obrad parlamentu. Sesje nadzwyczajne zwołuje Prezydent z własnej inicjatywy bądź m.in. na wniosek marszałka każdej z izb. Poza tym, założenia projektu Konstytucji nie określają pozycji ustrojowej marszałka Sejmu i marszałka Senatu. Sejm i Senat łącznie obradują jako Zgromadzenie Narodowe m.in. w celu zmiany ustawy zasadniczej.

Konstytucja Rzeczypospolitej Polskiej. Projekt Konfederacji Polski Niepodległej z 1991 r. Od pozostałych projektów odróżnia się rozbudowaną strukturą parlamentu, która zajmuje wiele miejsca w części III noszącej tytuł Sejm

16 Dz.U. PRL z 1976 r., Nr 5, poz. 29. 
Rzeczypospolitej. Projekt ten recypował do współczesnej Polski zmodyfikowaną konstrukcję trzech stanów sejmujących ukształtowaną w ciągu XVI w. Według projektu Konstytucji Konfederacji Polski Niepodległej (KP) „Sejm Rzeczypospolitej stanowi najwyższą władzę państwową" (art. 23). W jego skład wchodzą następujące stany sejmowe: Prezydent, Izba Poselska i Senat (art. 24). Kadencja Sejmu wynosi cztery lata. Iza Poselska liczy 444 posłów wybranych na cztery lata (art. 42). W skład Senatu wchodzi 124 senatorów, z czego 19 pochodzi z nominacji Prezydenta, a 105 kasztelanów wyłaniano w bezpośrednich wyborach (art. 47). Przyjęto sesyjny tryb obrad Izby Poselskiej, a system permanentnych obrad w Senacie. Sejm obradował na sesjach zwyczajnych. Natomiast uprawnienia do otwierania sesji nadzwyczajnej w obu izbach przyznano Prezydentowi. Organy wewnętrzne parlamentu pochodziły z wyborów (art. 43). Natomiast „Na wniosek Prezydenta wybiera ze swego grona Marszałka i wicemarszałków oraz komisje". Szczegółową regulację tej materii miał zawierać regulamin uchwalony przez Sejm dla Izby Poselskiej i Senatu (art. 55). Projekt Konstytucji KPN zawiera rozbudowaną strukturę organów pomocniczych Senatu, który mógł powoływać stałe komisje i podkomisje, jak i komisje nadzwyczajne, w tym komisje śledcze (art. 51). Omawiany projekt konstytucji wzorując się na instytucji izb połączonych z czasów Pierwszej Rzeczypospolitej przewidywał, że "Sejm obraduje jako Stany połączone: Prezydent, Izba Poselska, Senat”, przy czym „Obradom przewodniczą, w imieniu i na polecanie Prezydenta marszałkowie i wicemarszałkowie Izby Poselskiej i Senatu" (art. 55). Ponadto, w wypadku opróżnienia urzędu Prezydenta szereg ważnych czynności projekt konstytucji powierzał w pierwszej kolejności marszałkowi Senatu. Zgodnie z projektem „Jeżeli Prezydent nie wyznaczył następcy albo nie może on przyjąć urzędu, jako Prezydent zaprzysiężony zostaje Marszałek Senatu, a jeśli to niemożliwe Marszałek Izby Poselskiej..." (art. 40).

Według omawianego projektu konstytucji funkcje jednoosobowego organu kierowniczego w izbach spełniał marszałek Izby Poselskiej i marszałek Senatu, posiadający silniejsze umocnienie prawne $\mathrm{w}$ tym charakterze.

Projekt tez normatywnych nowej Konstytucji opracowany przez Mieczysława Huchlę w 1989 r. Strukturę i organizację parlamentu regulował rozdz. IV noszący tytuł Sejm i Senat Rzeczypospolitej Polskiej (tezy 29-37). Dwuizbowy parlament składał się z Sejmu (izba pierwsza) i Senatu (izba druga). W skład Sejmu wchodziło 460 posłów (teza 29), a do Senatu wybierano 100 senatorów (teza 33). Tak jak w pozostałych projektach konstytucji, uprawnienie do zwołania pierwszego posiedzenia nowo wybranego Sejmu i Senatu przyznano Prezydentowi. W projekcie tez M. Huchli przyjęto, że „Sejm wybiera ze swego grona marszałka, wicemarszałków i komisje” (teza 29), a nadto, iż „regulamin określa porządek prac Sejmu oraz liczbę i rodzaj komisji". Identycznie uregulowano strukturę organów wewnętrznych Senatu (teza 33). Zgodnie z projektem jedynie „Sejm może powołać doraźną komisję dla zbadania określonej sprawy, ..." 
(teza 29). Według projektu tez M. Huchli, organem kierowniczym w każdej $\mathrm{z}$ izb był marszałek, bądź $\mathrm{w}$ jego zastępstwie wicemarszałkowie $\mathrm{w}$ zakresie kompetencji wewnętrznych.

Projekt Konstytucji Rzeczypospolitej Polskiej opracowany przez Józefa Lityńskiego w 1990 r. Rozbudowane regulacje dotyczące parlamentu zawierają rozdziały: IV Sejm (art. 38-65), V Senat (art. 66-76) oraz VI Zgromadzenie Narodowe (art. 71-91). Zgodnie z projektem konstytucji J. Lityńskiego „Sejm jest podstawowym ciałem ustawodawczym Rzeczypospolitej ..." (art. 38). Sejm stanowił izbę niższa, a „Senat, jako wyższa Izba Ustawodawcza, spełnia funkcję czynnika stabilizującego w Parlamencie" (art. 66). Natomiast Zgromadzenie Narodowe stanowią wspólnie obradujący posłowie i senatorowie (art. 77). Do kompetencji tego organu należy w szczególności stwierdzenie ważności wyboru Prezydenta Rzeczypospolitej Polskiej oraz obsada urzędu wiceprezydenta (art. 78). Odmiennie, niż w pozostałych projektach konstytucji, ustalono liczbę posłów, a mianowicie od 450 do 540 pochodzących z bezpośrednich wyborów. Posłów wybierano na czteroletnią kadencję (art. 39). W skład Senatu wchodzili senatorowie także wybierani bezpośrednio, lecz na dłuższą, bo sześcioletnią kadencję (art. 67).

Sejm wybierał ze swego grona marszałka, który „przewodniczy obradom, spełnia funkcje powierzone mu przez Konstytucję i inne ustawy i jest odpowiedzialny za sprawy administracyjne związane z funkcjonowaniem Sejmu" (art. 32). Również Senat wybierał spośród swoich członków marszałka i wicemarszałków, w tym wypadku na pięcioletnią kadencję (art. 71). Członkowie Zgromadzenia Narodowego wybierają na czteroletnią kadencję przewodniczącego, którego zastępcami są marszałek Sejmu i marszałek Senatu (art. 77). Omawiany projekt konstytucji w ograniczonym zakresie określał strukturę organów wewnętrznych w obu izbach parlamentu. Na ich podstawie można uznać marszałka Sejmu za jednoosobowy organ kierowniczy izby niższej. Ograniczoną rolę w tym zakresie spełniał marszałek Senatu.

Konstytucja Rzeczypospolitej Polskiej. Projekt opracowany przez zespół pod kierownictwem Sylwestra Zawadzkiego w 1990 r. Projekt przyjął model jednoizbowego parlamentu - wcześniej wprowadzonego w Polsce Ludowej (od 1947 r.) - którego dotyczy rozdz. V Sejm Rzeczypospolitej Polskiej (art. 74-102). Projekt przyjmuje, że „Sejm Rzeczypospolitej Polskiej jest najwyższym organem przedstawicielskim, wyrażającym suwerenne prawa $\mathrm{Na}$ rodu" (art. 74). Liczebność Sejmu ustalono na 460 posłów przy zastosowaniu wariantowych zasad prawa wyborczego. Według wariantu I wybory miały być pięcioprzymiotnikowe, włącznie z zasadą proporcjonalności, a w wariancie II przewidziano jedynie czteroprzymiotnikowe (bez zasady proporcjonalności). Wprowadzono czteroletnią kadencję Sejmu, który przyjął sesyjny tryb pracy. Uprawnieniem Prezydenta było zwołanie pierwszego posiedzenia nowo wybranego Sejmu (art. 84). 
Status konstytucyjnych organów wewnętrznych izby omawiany projekt przyznał marszałkowi, Prezydium Sejmu i komisjom. Jednocześnie przyjęto, że "Organizację wewnętrzną i porządek prac Sejmu, jak też tryb powoływania i działalności jego organów określa regulamin uchwalony przez Sejm" (art. 90). Spośród posłów Sejm wybiera marszałka i wicemarszałków, którzy pod przewodnictwem marszałka stanowią Prezydium Sejmu. Organ ten „czuwa nad tokiem prac Sejmu i jego organów” (art. 85). Przewodniczenie obradom sejmowym stanowiło uprawnienie marszałka i jednego $\mathrm{z}$ wicemarszałków (art. 86). Organami pomocniczymi o wyspecjalizowanym charakterze były komisje sejmowe. Projekt rozróżnia komisje stałe i komisje niestałe (nadzwyczajne). Nadto „Sejm może powołać komisję dla zbadania określonej sprawy, wyposażoną $\mathrm{w}$ specjalne pełnomocnictwa $\mathrm{w}$ zakresie przesłuchiwania stron, wzywania świadków i rzeczoznawców, oraz inne uprawnienia niezbędne dla wyjaśnienia sprawy. Zakres działania oraz uprawienia komisji określa Sejm" (art. 89). Regulacja ta w istocie dotyczy komisji śledczej. W projekcie konstytucji opracowanym pod kierownictwem S. Zawadzkiego podstawowe zadania kierowania pracami Sejmu przyznano Prezydium Sejmu, będącym kolegialnym organem kierowniczym izby. Niektóre kompetencje tego organu nakładały się na uprawnienia marszałka. Istotne, że w tym projekcie szereg podstawowych postanowień dotyczy pozycji i roli komisji sejmowych.

Konstytucja Rzeczypospolitej Polskiej. Projekt opracowany przez Janinę Zakrzewską i Jerzego Ciemniewskiego w 1990 r. Regulacje dotyczące dwuizbowego parlamentu zawiera część 4 Sejm i Senat (art. 44-85). Zgodnie z projektem parlament składa się z Sejmu i Senatu. Sejm liczy 444 posłów wybieranych na czteroletnią kadencję (art. 44-45). Liczebność Senatu było zróżnicowana. Według wariantu A "Senat składa się ze 111 senatorów reprezentujących samorząd terytorialny, mniejszości narodowe oraz Polaków mieszkających za granicą", a według wariantu B "Senat składa się ze 100 senatorów wybranych przez województwa" (art. 67). Status konstytucyjnych organów wewnętrznych projekt konstytucji przyznał marszałkowi, wicemarszałkowi, sekretarzowi i komisjom wybranym spośród członków izb. Struktura tych organów jest identycznie uregulowana dla Sejmu i Senatu. Marszałek i wicemarszałek stanowią Prezydium Sejmu. Organ ten kieruje pracami Sejmu (art. 73). Odpowiednio określony skład Prezydium Senatu jest organem kierującym pracami izby drugiej (art. 73). Natomiast marszałek Sejmu, a w jego zastępstwie wicemarszałek oraz marszałek Senatu, w jego zastępstwie wicemarszałek przewodniczy obradom $w$ każdej $z$ izb. Identycznie określono strukturę organów pomocniczych obu izb, to jest komisji (bez rozróżnienia) sekretarzy (art. 53, 73). Natomiast według projektu konstytucji jedynie „Sejm może powoływać komisje nadzwyczajne i śledcze dla zbadania określonej sprawie" (art. 54). Projekt przewidywał określenie organizacji i trybu prac izb w odrębnym regulaminach uchwalonych przez Sejm (art. 57) i Se- 
nat (art. 76). W projekcie Konstytucji J. Zakrzewskiej i J. Ciemniewskiego kolegialnym organem kierowniczym w izbach było Prezydium Sejmu i Prezydium Senatu.

Projekt Konstytucji Rzeczypospolitej Polskiej opracowany przez Andrzeja Mycielskiego i Wacława Szyszkowskiego w 1991 r. Problematyka dwuizbowego parlamentu przedstawiona jest $\mathrm{w}$ rozdz. III Władza ustawodawcza (art. 25-54). Według projektu Sejm składa się z dwóch Izb ustawodawczych, to jest Izby Poselskiej i Senatu (art. 24). Kadencje obu izb wynoszą cztery lata. Skład Izby Poselskiej jest wyłaniany na podstawie czteroprzymiotnikowego prawa wyborczego (art. 26). Senatorowie mieli być wybierani w głosowaniu pośrednim. Odrębne ordynacje wyborcze uregulują zasady wyboru do każdej z izb, w tym liczbę posłów i senatorów. Zgodnie z projektem zwoływanie, odraczanie i zamykanie sesji w Izbie Poselskiej i Senacie stanowiło uprawnienie Prezydenta (art. 43).

Projekt ogranicza się jedynie do wyliczenia organów wewnętrznych w Izbie Poselskiej (bez określenia ich pozycji ustrojowej). Regulacja ta odnosi się także do Senatu. Projekt przewiduje wybór spośród posłów marszałka, jego zastępców, sekretarzy i komisji (bez rozróżnienia). Rozwiązanie to ma też zastosowanie do Senatu. Jednocześnie ustalono, że „Porządek obrad Izby Poselskiej, prawa i obowiązki Marszałka, liczbę zastępców Marszałka i sekretarzy, rodzaj i liczbę komisji określa regulamin Izby" (art. 38). Odpowiednia regulacja dotyczy Senatu. Z treści projektu Konstytucji A. Mycielskiego i W. Szyszkowskiego wynika jedynie, że jednoosobowym organem kierowniczym w Izbach są Marszałek Izby Poselskiej i Marszałek Senatu. Organem pomocniczym w każdej z Izb są sekretarze i komisje.

Dokonany przegląd struktury organów wewnętrznych zawartej w projektach konstytucyjnych z lat 1989-1991 uwidacznia charakter i zakres adaptacji w nich postanowień ustawy zasadniczej z 22 lipca 1952 r. (przed nowelizacjami z 1989 r.). Problematyka ta jest przedmiotem regulacji rozdz. 3 Naczelne organy władzy państwowej (art. 20-33). Jednoosobowy Sejm składał się z 460 posłów wybieranych na czteroletnią kadencję (art. 21, 28). Nieliczne postanowienia Konstytucji lipcowej regulowały strukturę systemów wewnętrznych Sejmu. Konstytucyjny status uzyskały następujące organy: marszałek i wicemarszałkowie oraz komisje stałe pochodzące $\mathrm{z}$ wyborów dokonanych spośród posłów. Zgodnie z ustawą zasadniczą z 22 lipca 1952 r. marszałek lub wicemarszałek „kieruje obradami i czuwa nad tokiem prac Sejmu" (art. 23). Postanowienia te były rozwijane w kolejnych regulaminach sejmowych. Według Regulaminu Sejmu Polskiej Rzeczypospolitej z dnia 17 lipca 1986 r. ${ }^{17}$ organami Sejmu są także Prezydium Sejmu, Konwent Seniorów i sekretarze (art. 15, 25). Prezy- 
dium Sejmu - składające się z marszałka i wicemarszałków - było najwyższym organem wewnętrznym Sejmu, o charakterze kolegialnym. Organ ten kierował pracami Sejmu, co oznaczało, że spełniał podstawowe funkcje wśród organów kierowniczych parlamentu. Marszałek (wicemarszałkowie) uzyskali własny zakres kompetencji w zakresie funkcjonowania Sejmu. Reaktywowany Konwent Seniorów - o charakterze polityczno-doradczym - stał się organem pomocniczym Prezydium Sejmu.

Dla dalszych rozważań istotne znaczenie mają postanowienia Ustawy Konstytucyjnej o wzajemnych stosunkach między władzą ustawodawczą i wykonawczą Rzeczypospolitej Polskiej oraz o samorządzie terytorialnym wraz z pozostałymi przepisami konstytucyjnymi z dnia 17 października $1992 \mathrm{r}$. (Mała Konstytucja) ${ }^{18}$. Była to konstytucja niepełna. Akt ten doszedł do skutku „W celu usprawnianie działalności naczelnych władz Państwa, do czasu uchwalenia nowej konstytucji Rzeczypospolitej Polskiej...". Regulacje dotyczące utrzymanego dwuizbowego parlamentu zamieszczono głównie w rozdz. 2. Sejm i Senat (art. 3-27). Sejm stanowił izbę pierwszą o silniejszej pozycji wobec izby drugiej („izba refleksji”), jaką był Senat. Obie izby obradujące wspólnie pod przewodnictwem marszałka Sejmu stanowiły Zgromadzenia Narodowe (art. 27). Sejm liczył 460 posłów pochodzących z pięcioprzymiotnikowych wyborów. W skład Senatu wchodziło 100 senatorów wyłonionych w czteroprzymiotnikowych wyborach. Kadencja obu izb wynosiła cztery lata (art. 3).

Szereg postanowień Małej Konstytucji z 1992 r. regulowało strukturę organów wewnętrznych obejmującą organy kierownicze i pomocnicze (art. 10). Sejm wybierał spośród posłów marszałka, wicemarszałków i komisje. Marszałek Sejmu jest jednoosobowym organem kierowniczym izby. Marszałek i wicemarszałkowie tworzyli Prezydium Sejmu, będące organem kolegialnym. Statusu organu konstytucyjnego nie posiadał Konwent Seniorów, odgrywający ważną rolę polityczną, będąc organem pomocniczym Prezydium Sejmu. Zgodnie z aktem z 17 października 1992 r. Prezydium Sejmu „zwołuje posiedzenia Sejmu i kieruje jego pracami", co stanowi najważniejsze kompetencje tego organu. Akt ten nie określał uprawnień marszałka Sejmu. Zgodnie z regulaminem marszałek przewodniczył obradom Sejmu oraz wykonywał szereg ważnych kompetencji zewnętrznych. Wymienione w Małej Konstytucji z 1992 r. komisje sejmowe były organami pomocniczymi, poddane kierownictwu Prezydium Sejmu. Akt z 1992 r. określający pozycję ustrojową Sejmu odnosi się w zasadzie do Senatu (art. 26), z tym, że często marszałek Senatu występuje jako zastępca marszałka Sejmu. Konstytucyjny model struktury organów wewnętrznych zawarty w akcie z 1992 r. uległ istotnej modyfikacji w Konstytucji Rzeczypospolitej Polskiej z 2 kwietnia 1997 r. Akty konstytucyjne z 1952, 1989 i 1992 r. zawierają zróżnicowane regulacje określające pozycję ustrojową marszałka w parlamencie. 
Charakteryzowane w opracowaniu projekty konstytucyjne z lat 1989-1991 zawierają zróżnicowane $\mathrm{w}$ formie $\mathrm{i}$ treści konstrukcje ustrojowe. $\mathrm{W}$ silnym stopniu nawiązują do polskiej tradycji parlamentarnej. Wzorem Pierwszej Rzeczypospolitej przyjęto nazewnictwo izb parlamentarnych: Izba Poselska i Senat na oznaczenie Sejmu (4 projekty). Więcej projektów przyjęło rozwiązanie z okresu II Rzeczypospolitej i początków Polski Ludowej (do 1952 r.), to znaczy określenie Sejmu i Senatu na izby parlamentarne (izba pierwsza i izba druga), które występują w sześciu projektach. W ten sposób przywrócono dwuizbowość polskiego parlamentu. Jedynie projekt konstytucji opracowany pod kierownictwem S. Zawadzkiego utrzymywał jednoizbowy parlament w postaci Sejmu liczącego 460 posłów. Znamienne, że w 6 projektach izba niższa liczy 444 posłów, a tylko w dalszych 4 projektach liczy 460 posłów. Znowelizowana w 1960 r. ustawa zasadnicza z 1952 r. postanawiała, że Sejm liczy 460 posłów (art. 21). Tę liczbę posłów w Sejmie wymieniała nowela konstytucyjna z 7 kwietnia 1989 r., a następnie akty konstytucyjne z 1992 i 1997 r. Odnośnie Senatu występuje znaczne zróżnicowanie w określeniu charakteru i składu tego organu, liczącego najczęściej 100 lub 111, a wyjątkowo nawet 124 senatorów. W większości projektów konstytucji marszałkom izb przyznano zróżnicowane co do zakresu kompetencje jako jednoosobowego organu kierowniczego. Jedynie $w$ dwóch projektach zamieszczono tradycyjną formułę, że „Prezydium kieruje pracami Sejmu” (Senatu). Silna pozycja tego organu o charakterze kolegialnym zapewniała przewage nad marszałkami Sejmu i Senatu. Dotyczy to sejmowego projektu konstytucyjnego oraz projektu opracowanego przez J. Zakrzewską i J. Ciemniewskiego. Widoczne w tym wypadku jest nawiązanie do przepisów Regulaminu sejmowego z 1986 r. Natomiast w projektach konstytucji: senackim, Stronnictwa Demokratycznego oraz w projekcie opracowanym pod kierownictwem S. Zawadzkiego określenie pozycji i roli Prezydium Sejmu odesłano do regulacji regulaminowej.

Przyjmując za punkt odniesienia strukturę organów wewnętrznych Sejmu i Senatu zawartą w Małej Konstytucji z 17 października 1992 r., to najbardziej zbliżone do tego modelu były postulowane regulacje zawarte $\mathrm{w}$ sejmowym projekcie Konstytucji z 1991 r. oraz w projekcie opracowanym przez J. Zakrzewską i J. Ciemniewskiego w 1990 r.

\section{Bibliografia}

Ustawa z z dnia 10 lutego 1976 r. o zmianie Konstytucji Polskiej Rzeczypospolitej Ludowej (Dz.U. PRL z 1976 r., Nr 5, poz. 29). 
Ustawa z dnia 7 kwietnia 1989 r. o zmianie Konstytucji Polskiej Rzeczypospolitej Ludowej (Dz.U. PRL 1989 r., Nr 19, poz. 101).

Ustawa Konstytucyjna o wzajemnych stosunkach między władzą ustawodawczą i wykonawczą Rzeczypospolitej Polskiej oraz o samorządzie terytorialnym wraz z pozostałymi przepisami konstytucyjnymi z dnia 17 października 1992 r. (Dziennik Ustaw Rzeczypospolitej Polskiej z 1992 r., Nr 84, poz. 426).

Regulamin Sejmu Polskiej Rzeczypospolitej z dnia 17 lipca 1986 r. (Monitor Polski z 1986 r., Nr 21, poz. 151)

Porozumienia Okragłego Stołu. Warszawa 6 luty - 5 kwietnia 1989 r., Olsztyn 1989.

Chruściak R., Osiatyński W., Tworzenie konstytucji w Polsce w latach 1989-1997, Warszawa 2001.

Projekty konstytucyjne 1989-1991, do druku przygotował M. Kallas, Warszawa 1992. 